\title{
Inuit Seal Hunting in Canada: Emerging Narratives in an Old Controversy
}

\author{
Samantha D. Farquhar ${ }^{1}$ \\ (Received 9 July 2019; accepted in revised form 8 November 2019)
}

\begin{abstract}
Seal hunting in Canada is a historically controversial topic. Animal rights groups have campaigned that Atlantic Canadians inhumanely slaughter thousands of "baby" seals every year. The work of these animal rights groups has led to changes in national fisheries regulations and markets. The market changes have greatly affected the livelihoods of many Atlantic Canadians, but even more so of the Inuit who also hunt seals in Canada's Arctic regions. Animal rights groups largely excluded and ignored the Inuit who depended on the larger Atlantic Canadian seal market. However, Inuit have recently mobilized though social media to reclaim the narrative surrounding seal hunting. Their campaign has helped change national policy. The Government of Canada has since created a scheme to increase market access to Inuit-harvested seals. Yet, little information is available for this scheme and its effectiveness needs to be further investigated.
\end{abstract}

Key words: seal hunting; Canada; Inuit; Indigenous activism; narratives; animal rights; Arctic resources; fisheries management; market access; sealskin products

RÉSUMÉ. Au Canada, la chasse au phoque est un sujet qui porte à controverse depuis fort longtemps. Des groupes de défense des animaux ont mené une campagne soutenant que les Canadiens de la région atlantique massacrent inhumainement des milliers de " bébés » phoques chaque année. Le travail de ces groupes de défense des droits des animaux a mené à des modifications à la réglementation et aux marchés de la pêche au niveau national. L'évolution du marché a eu une grande incidence sur les moyens de subsistance de nombreux Canadiens de la région de l'Atlantique, mais encore plus sur les Inuits qui chassent également le phoque dans les régions arctiques du Canada. Les groupes de défense des animaux ne se sont à peu près pas préoccupés des Inuits qui dépendaient du marché canadien du phoque de la région atlantique dans son ensemble. Cependant, les Inuits se sont mobilisés récemment par l'intermédiaire des médias sociaux pour récupérer le récit entourant la chasse au phoque. Leur campagne a favorisé la modification de la politique nationale. Depuis, le gouvernement du Canada a créé un mécanisme visant à accroître l'accès au marché des phoques capturés par les Inuits. Cependant, il existe peu de renseignements au sujet de ce programme et son efficacité doit être examinée de plus près.

Mots clés : chasse au phoque; Canada; Inuit; activisme autochtone; récit; droits des animaux; ressources arctiques; gestion des pêches; accès au marché; produits en peau de phoque

Révisé pour la revue Arctic par Nicole Giguère.

\section{INTRODUCTION}

Seal hunting in Atlantic Canada has been highly controversial since the 1970s (Chaussade, 1978; Thornton, 1978; Sumner, 1983). In this region, harp, hooded, grey, ringed, bearded, and harbor seals (with harp seals being most popular) are harvested via firearm, club, or hakapik (a club-like tool fitted with a hammer and hook) (DFO, 2011). Animal Rights (AR) media groups (e.g., Greenpeace, International Fund for Animal Welfare, People for the Ethical Treatment of Animals [PETA]) pushed a villainhero-victim narrative that thousands of seals were immorally "slaughtered" every year. They portrayed seal pups as victims, Atlantic sealers as villains, and AR groups and those who support their cause as heroes (Harter, 2004; Sanger, 2010; Dauvergne and Neville, 2011).
Ultimately, environmental lobbying attached to this narrative led many nations to refuse to trade seal products in the 21st century (e.g., Mexico in 2006, the Netherlands and Belgium in 2007, the European Union [EU] in 2009, Russia in 2011). Most recently in 2018, India joined the 36 other countries that have already boycotted seal items. With so few markets now available, the fishery has significantly lost its value. While the majority of sealers - those from fishing communities in Québec, Newfoundland and Labrador, and Nova Scotia-hunt seals when their main fisheries are out of season, Indigenous groups such as the Inuit, who have hunted seals for over 3000 years regardless of imposed seasons, were severely affected (Lafrance, 2017).

The Inuit live in remote areas and have access to very few global commercial markets. They were largely excluded from discussions surrounding commercial seal

\footnotetext{
${ }^{1}$ School of Marine and Environmental Affairs, University of Washington, Box 355685, Seattle, Washington 98195-5685, USA; farquharsamantha6@gmail.com

(C) The Arctic Institute of North America
} 
hunting because it was wrongly assumed that they only participated on the subsistence level. This assumption was due to lack of understanding and the propaganda promoted by AR that only portrayed Atlantic sealers as commercial sealers. While some of the seal bans have exceptions for Inuit-harvested seals, the lack of markets caused by the bans has made those exceptions useless (Hossain, 2013). Though Inuit groups met with EU lawmakers and AR groups on a number of occasions to clarify their participation in the global market and insist that an exemption to the EU ban would be pointless, their appeals were dismissed. However, a new narrative is emerging and challenging that of the prominent AR groups. This narrative is Inuit led and identifies seal use as critically important to Inuit survival, culture, and economy (Rodgers and Scobie, 2015; Hawkins and Silver, 2017; Knezevic et al., 2018; Searles, 2019). For the first time, this narrative is being widely disseminated. The Inuit are using innovative methods such as lawsuits, fashion, protests, and notably strategic social media campaigns to make their voices heard (Arnaquq-Baril, 2016; Hawkins and Silver, 2017; O'Connor et al., 2017; Knezevic et al., 2018).

\section{WHAT IS A NARRATIVE?}

A narrative can be defined in its simplest form as a story (Leavy, 2015). Narratives are meant to resonate deeply with audiences and help them make sense of otherwise complex issues (Boje, 2001). Policy makers often use narratives to guide organizational action and influence responses (Gioia and Chittipeddi, 1991; Abolafia, 2010). For example, dolphin protection campaigns in the United States spread the narrative that countless dolphins die as a result of tuna fishing activities; this narrative led to "Dolphin-safe" tuna labels and the Dolphin Protection Consumer Information Act (Wright, 2000). The effectiveness of these programs has since been questioned (Murphy, 2006; Miller and Bush, 2015). In academia, climate change-related papers written in narrative style were cited more often than papers written objectively (Hillier et al., 2016). More recently, narratives are being spread faster than ever through the use of social media, and the emergence of "hashtag activism." Hashtags allow narratives to be coined in a single phrase and spread rapidly. This yields powerful results. For example, \#BlackLivesMatter invoked a new civil rights dialogue and allowed for narratives surrounding injustices towards black people to be widely shared (Yang, 2016). Similarly, \#FlintWaterCrisis spread the narrative of a public health crisis focused on government inaction over lead content in drinking water, eventually resulting in national legislative action to remedy this health concern (Moors, 2019). While narratives can be an effective way to incite change, the use of narratives can be misused to promote false information or offer oversimplifications of multifaceted issues, which can lead to oversight in decision making.
Given the importance, power, and facile dissemination of narratives, this paper follows how narratives impacted the seal fishery in Canada. I investigate the facts surrounding the seal hunt in the Atlantic and the Arctic and compare these facts to the AR group's narratives. I explore the consequences of these narratives as felt by the Inuit, and describe and explore the impacts of the current counter narratives-especially how these counter narratives have improved markets for seal products from Inuit communities.

\section{THE ATLANTIC COMMERCIAL SEAL FISHERY}

Six species of seals-harp, hooded, grey, ringed, bearded, and harbor-are found off the Atlantic coast of Canada where the commercial seal harvest takes place. Yet, harp seals account for almost all the seals harvested commercially in Canada. Harp seals spend their summers in the Canadian Arctic and Greenland and migrate south in the fall to reach the southern Labrador coast (DFO, 2011). Some mature seals will then travel up the Gulf of St. Lawrence, while the rest migrate south to Newfoundland. Typically, the commercial harvest for harp seals occurs between November and June (DFO, 2011).

The commercial seal fishery is made up of sealers from fishing communities throughout Nova Scotia, Québec, New Brunswick, Prince Edward Island, and Newfoundland and Labrador. The harvest acts as seasonal income and food when their main fisheries are closed and other employment opportunities are limited. Sealing makes up $25 \%-35 \%$ of their total income (GNL, 2018). For many coastal communities in these provinces, marine resources are integral to their identity, history, and culture and are valued beyond economics. For example, specialty shops in Newfoundland commonly sell sealskin clothing, sealflipper pie, and seal sausages (Sellheim, 2014).

Fisheries and Ocean Canada (DFO) is the principal management authority for the seal fishery. The issuance of sealing licenses is strictly governed by the Commercial Fisheries Licensing Policy for Eastern Canada (1996), created under the authority of the Fisheries Act (Lafrance, 2017). Each commercial sealer must obtain a license to participate in the harvest. While approximately 16000 commercial licenses are currently held by individuals, only around 6400 are presently active in the harvest.

Laws were first enacted in 1895 in Newfoundland to protect dwindling seal populations. A closing date to protect adult females was first imposed in 1961 and hunting by aircraft was banned in 1970 . The first quota management system was put in place for seals in 1971 (Barry, 2005). Before the quota, fishermen were harvesting an average of 285600 seals a year $(1952-70)$. In 1987, DFO banned the commercial harvesting of newborn harp seals (whitecoats) and newborn hooded seals (bluebacks) and put restrictions on the size of vessels allowed to hunt. In 2008, new laws aimed at ensuring a more humane seal harvest required 
sealers to follow a three-step, science-based process of striking, checking, and bleeding the seal (DFO, 2011). Struck in collaboration with the Independent Veterinarians Working Group, the three-step process codified the already established harvesting practices. It was finally adopted by DFO after extensive lobbying by seal hunter groups via the Fur Institute of Canada's Seals and Sealing Network. Similarly, professional training and a code of conduct were initiated by the hunters who pressured DFO to write the regulations (Lafrance, 2017). This initiative was a counterstrategy to the propaganda narratives perpetuated by the AR groups. Since these regulations have been put in place, the harp seal population has tripled and currently stands at 7.4 million animals (Lafrance, 2017).

While different input regulations have changed the way sealers harvest, the concept remains the same-although preference differs between the Newfoundland and Gulf of St. Lawrence seal hunting regions. During the season, sealers use their fishing vessels or snowmobiles to gain access to ice where seals are hauled out. They then quickly approach the seal and either shoot it with a shotgun or rifle, or strike it with a regulated club or hakapik. The seal is then processed a short time later for its oil, meat, and pelt and sold directly to processing centers, which then sell to domestic and international markets.

\section{THE INUIT SEAL FISHERY}

Inuit live in four Arctic regions of Canada: Northwest Territories, Nunavut, Nunavik (Québec), and Nunatsiavut (Labrador). The Inuit have hunted bearded seals, harp seals, ringed seals, and harbor seals for thousands of years (Peter et al., 2002). However, ringed seals are the most commonly sold to markets. Seals are part of Inuit identity, culture, and spirituality. Seals are a vital and culturally relevant food source for the Inuit - other nutrition options are often expensive, scarce, and nutritionally deficient. The Inuit do not need a license to hunt seals year-round (DFO, 2011), consequently no records exist to provide the number of hunters participating in the fishery and the number of seals taken. However, in Nunavut alone, it is estimated that there are 6000 people active in year-round seal harvesting (GN, 2012). From a ringed seal population projected to number between 1.5 and 3 million, an estimated 30000 are harvested annually (GN, 2012).

Inuit hunt seals by traveling to sea ice via snowmobiles, dog-sled teams, or small boats. They wait at seal breathing holes, search the ice for hauled out seals, or look for seals swimming. They will shoot the seal with a rifle or shotgun. Occasionally more traditional gear, such as a harpoon, is used (Pelly, 2001). Later, the seal is processed and used for food and traditional clothing. It takes approximately 3-4 sealskins to make a man's traditional parka (Peter et al., 2002). Historically, the Inuit began participating in the Canadian economy through bartering and selling their goods to the Hudson's Bay Company (Peter et al., 2002).
Presently, the Inuit sell sealskins for income to provincial and territorial government offices. Government officials then transport the pelts to a designated fur auction which international and domestic buyers attend. Inuit often also sell the pelts directly to auction houses.

\section{ANIMAL RIGHTS MEDIA GROUPS' NARRATIVES}

The seal hunt in Canada became a source of controversy beginning in the 1950s and 1960s, and strong anti-sealing activism followed in the 1970s (Foote, 1967; Wenzel, 1991). First, footage of the hunt was taken by Harry Lille, a medical officer abroad a sealing ship. In 1964, a documentary that reached a global audience showed sealers "skinning a seal alive." Later it was found that the seal skinning was staged and did not occur during the hunt (Barry, 2005). Despite this false information, the world was angered. DFO was suddenly under immense pressure and began adopting new regulations. However, these new regulations did not satisfy the AR groups or the public who were determined to prevent seal hunting altogether. AR groups pushed a villain-hero-victim narrative. Such narratives are known to be captivating, politically strategic, and can trigger deep emotional responses (Herzog and Galvin, 1992; Bergstrand and Jasper, 2018). At the core of the AR campaign was the term "baby" seal, which imbued seal pups with a sense of innocence and need for protection (Dauvergne and Neville, 2011). By victimizing the seals, the hunters became the villain. This narrative was further enhanced through the use of emotional language and imagery, celebrity endorsements, and dramatic street protests. Atlantic Canadian sealers were seen as "monsters" who "slaughtered" thousands of innocent animals and represented "Canada's shame" (Barry, 2005). This easily allowed the AR groups and their supporters to fill the role of hero. These campaigning strategies paid off, and in 1983 whitecoat seal products were banned in the EU. This ban motivated DFO to prohibit the commercial hunt of whitecoats and bluebacks in 1987.

Even after they were no longer hunted in Canada after the 1987 rule change, fluffy, whitecoat seal pups were still the image of the seal hunt and almost led to a collapse of the sealing industry in the late 1980s (Dauvergne and Neville, 2011). The AR groups championed this as a great victory. However, in the $1990 \mathrm{~s}$, the industry began to recover through government subsidies (Dauvergne and Neville, 2011). By the early 2000s, sealing yields were higher than they had been in decades. Such high yields led to more attention by the AR groups who continued to promote misinformation (Beylier, 2012). As little more than a publicity stunt in 2005, the U.S. Humane Society called for a Canadian seafood boycott until the seal hunt was discontinued (CBC News, 2005). Intense campaigning combined with the global financial crisis of 2007-08 led to record low prices for seal products. In 2009, AR groups swayed EU representatives, which resulted in the European 
Parliament and Council adopting Regulation (EC) No 1007/2009 based on moral grounds. This regulation, which was a continuation of the rationalization that drove the 1987 ban, did leave an exemption so that seal pelts from Inuit harvesters could continue to be imported.

\section{THE INUIT COUNTER-NARRATIVE}

After the $2009 \mathrm{EU}$ ban, the Inuit narrative gained attention. They stated that the EU ban devastated their communities. Given the differences between the two hunts, they were disgruntled at being associated with the Atlantic seal hunt (Peter et al., 2002). Though many AR groups and the Canadian Green Party had for decades been aware of the Inuit reliance on seals, policy makers did not understand the extent to which the Inuit hunt contributed to the international market, nor did they consider that the Inuit sealskin market would be dependent on the demand resulting from the Atlantic seal fishery.

However, this was neither the first time that a seal product ban had affected the Inuit nor the first time they had been ignored. A year after the 1987 ban, the average income of an Inuit seal hunter in Nunavut fell from 53000 to 1000 dollars (Arnaquq-Baril, 2016). Although an Inuit exemption was declared in the 1987 ban as well, consumers did not differentiate Atlantic harp sealskins from Nunavut ringed sealskins (Wenzel, 1987). The demand dropped; all sealskin sales came to a halt, and the markets for ringed sealskins from Nunavut disappeared. Sales dropped from 50000 pelts in 1977 to less than 1000 in 1988 (GN, n.d.).

Thus, Regulation 1007/2009 and its exemption for the Inuit was similar to past exemptions - it was vague and lacked any implementation procedures (Hossain, 2013). As the Government of Nunavut (2012:10) explained,

Due to the wording of Regulation 1007/2009, if an EU manufacturer were to purchase Inuit-harvested ringed seal skins, it would be illegal to place on the market anything manufactured from these skins, as the finished product would no longer be considered an Inuit produced seal product...not only was the Inuit market demand effectively crushed by the ban, but international fur buyers and brokers were unwilling to risk purchasing Inuit produced seal products due to the uncertainties surrounding international shipment of these products and trans-shipment through the EU.

Because of the Regulation's severe economic implications to both Atlantic and Inuit seal fisheries, Canada and Norway filed a joint appeal with Inuit groups in late 2009. However, the EU dismissed the appeal and again AR groups declared victory (Hossain, 2013). More celebrities began siding with anti-sealing campaigns; fewwith the exception of Anthony Bourdain - allied with the Inuit (CBC News, 2013). However, after Ellen DeGeneres posted a record-breaking selfie from the 2014 Oscars and donated money for every retweet to the Humane Society of the United States, which campaigns against the seal hunt, the Inuit mobilized. The Inuit came together online and reclaimed the seal hunt dialogue. Playing on "\#selfie," the Inuit started an online trend using "\#sealfie." Photos of Inuit with seals or seal products accompanied this hashtag. These tweets allowed the Inuit to take control of the dialogue about the seal hunt by promoting the use of seal for their survival, their respect for seals, and its economic importance (Rodgers and Scobie, 2015; Hawkins and Silver, 2017; Knezevic et al., 2018; Searles, 2019). In that same year, when Inuit vocal artist Tanya Tagaq won the Polaris Music Prize, she boldly encouraged viewers to eat and wear seal and added "Fuck PETA" in her acceptance speech (Newman, 2014). Later in 2016, Inuit filmmaker Alethea Arnaquq-Baril released her award-winning documentary, Angry Inuk. This film captured the continuous impacts that the actions of AR groups have had on Inuit communities (Arnaquq-Baril, 2016).

\section{IMPACTS}

Ultimately, the counter-narrative led by Inuit against AR groups allowed them to reclaim a dialogue that had historically marginalized and excluded them. This counternarrative was fortified by hashtag activism, film, music, celebrity endorsement, fashion, and news coverage. Even though the counter-narrative has always existed, social media and other innovative strategies have recently allowed it to grow and spread. This momentum was further strengthened when other lobby groups teamed up with the Inuit movement. As before, the Fur Institute of Canada's Seals and Sealing Network, which represents sealers from all regions, asked for more support from the Government of Canada. In May 2016, the government hosted an event called "Seal Day on The Hill" to promote seal products and to show the government's support. That same day, Fisheries Minister Hunter Tootoo announced a 5.7 million dollar fund for developing and marketing Inuit-harvested seal products (GC, 2016). This fund became known as the "Certification and Market Access Program for Seals (CMAPS). Almost exactly a year later, the government designated a new holiday, "National Seal Products Day" to recognize again the importance of the seal hunt for Canada's "Indigenous people, coastal communities, and entire population" (GC, 2017:2).

Economically, the Inuit counter-narrative has increased domestic interest in sealskin garments. The recent CMAPS scheme is working to address the sealskin trade internationally, as an official certification program had to be put in place to comply with the EU exemption and give consumers confidence. Thus, recognized certifying bodies are established through CMAPS in Canada to verify seal products as "Inuit-harvested" so that they can be approved by the EU. Currently, only two certifying bodies are recognized in Canada: the Government of Nunavut and the 
Government of the Northwest Territories. As before, Inuit sell their seal pelts to the governmental officers who then certify they were Inuit-harvested. The government then issues a specific QR Code (Quick Response code) label and an attesting document to the seal product and sells to an international fur-auctioning house (GNWT, 2017; European Commission, 2019). In addition to funding projects that support Inuit-harvested seal products, CMAPS also works to increase market access opportunities for commercially harvested Atlantic seal products (DFO, 2017). Presently, China and other Asian nations appear to be emerging destinations for seal products (CBC News, 2015; He, 2015; Lafrance, 2017). If market demand for Atlantic seal products continues to rise in Asian markets, it can be expected that demand for Inuit-harvested sealskins will follow.

However, while the CMAPS scheme has provided the infrastructure for Inuit marketing, it is unclear just how much it has aided the Inuit or if other Arctic regions are working to become recognized as certifying bodies. Trade data from this scheme are still being collected and are not publicly available to date. Overall, seal exports were still in decline between 2004 and 2016. Thus, it will likely take more than the 5.7 million dollar fund to revive and support Inuit-harvested seal products and the Atlantic sealing industry.

\section{CONCLUSION}

While narratives can be used for marginalizing and silencing social groups, marginalized groups can likewise use narratives effectively as a defensive response. The Inuit have historically been marginalized in political, economic, and social domains (Bonesteel, 2008). The narratives put forth by the AR groups contributed to this marginalization when they failed to distinguish the Atlantic seal hunt from the Inuit seal hunt. It is now clear that while they share the same market, these are two distinct fisheries targeting different species at different scales. Though Greenpeace has formally apologized to the Inuit for causing such harm, other AR groups have refused (Kerr, 2014; Watson, 2016). Narratives and their dissemination via social media allow for grassroots campaigns that otherwise would have taken millions of dollars to complete. These types of campaigns are becoming essential to Indigenous people. For example, the Standing Rock Sioux's online protest of the Dakota Access Pipeline led to international protests and millions of dollars of donations (Johnson, 2017). Similarly, after forced closure of Aboriginal communities in Australia, young Indigenous Australians undertook a social media campaign that led to a global outcry (Dreher et al., 2016). As we continue to live in a digital age, it is expected more Indigenous peoples will harness social media platforms to make their voices heard and motivate social change (Alia, 2010).
Nevertheless, the campaign against the seal hunt is still ongoing. Despite the fact the Inuit are now more recognized in this battle, they will continue to suffer the consequences if the overall industry remains in decline. Given that the Inuit are already in an extremely vulnerable position because of food insecurity and climate change, political actors should listen to these narratives and be ready and willing to provide support as directed (Ford et al., 2008; Laidler et al., 2009; Ford and Pearce, 2012; Council of Canadian Academies, 2014; Wenzel et al., 2016; Kenny and Chan, 2017). Information on the CMAPS program should be made more available to understand if it is aiding the Inuit. If not, the Inuit should be consulted as other programs are developed.

\section{ACKNOWLEDGEMENTS}

Special thanks to the Canadian Studies Center at the University of Washington and the Foreign Language and Area Studies Fellowship. This work would not have been possible without the support of these great institutions.

\section{REFERENCES}

Abolafia, M.Y. 2010. Narrative construction as sensemaking: How a central bank thinks. Organization Studies 31(3):349-367. https://doi.org/10.1177/0170840609357380

Alia, V. 2010. The new media nation: Indigenous peoples and global communication. New York: Berghahn Books.

Arnaquq-Baril, A. 2016. Angry Inuk. Documentary film. Montreal, Quebec: National Film Board of Canada.

Barry, D. 2005. Icy battleground: Canada, the International Fund for Animal Welfare, and the seal hunt. St. Johns, Newfoundland: Breakwater Books.

Bergstrand, K., and Jasper, J.M. 2018. Villains, victims, and heroes in character theory and affect control theory. Social Psychology Quarterly 81(3):228-247.

https://doi.org/10.1177/0190272518781050

Beylier, P.-A. 2012. La chasse au phoque: Entre information et désinformation. Études Canadiennes/Canadian Studies 73:91- 108 .

https://doi.org/10.4000/eccs.293

Boje, D.M. 2001. Narrative methods for organizational and communication research. Thousand Oaks, California: SAGE Publishing.

Bonesteel, S. 2008. Canada's relationship with Inuit: A history of policy and program development. Ottawa: Indian and Northern Affairs Canada.

CBC News. 2005. U.S. Humane Society calls for Canadian seafood boycott. April 4.

https://www.cbc.ca/news/canada/u-s-humane-society-callsfor-canadian-seafood-boycott- 1.555565 
2013. Anthony Bourdain goes to bat for Canadian seal hunt. October 29.

https:/www.cbc.ca/news/canada/newfoundland-labrador/ anthony-bourdain-goes-to-bat-for-canadian-sealhunt-1.2286476

. 2015. Why China just may be the seal hunt's last hope. November 24.

https://www.cbc.ca/news/canada/newfoundland-labrador/ china-seal-hunt-1.3327509

Chaussade, J. 1978. Faut-il supprimer la chasse aux bebe-phoques? Esprit 15(3):90-94.

Council of Canadian Academies. 2014. Aboriginal food security in northern Canada: An assessment of the state of knowledge. The Expert Panel on the State of Knowledge of Food Security in Northern Canada. Ottawa: Council of Canadian Academies.

Dauvergne, P., and Neville, K.J. 2011. Mindbombs of right and wrong: Cycles of contention in the activist campaign to stop Canada's seal hunt. Environmental Politics 20(2):192-209. https://doi.org/10.1080/09644016.2011.551024

DFO (Fisheries and Oceans Canada). 2011. 2011-2015 integrated fisheries management plan for Atlantic seals. https://www.dfo-mpo.gc.ca/fisheries-peches/seals-phoques/ reports-rapports/mgtplan-planges20112015/mgtplanplanges20112015-eng.html\#cl

_ 2017. Certification and market access program for seals. https://www.dfo-mpo.gc.ca/fisheries-peches/seals-phoques/ certification-eng.html

Dreher, T., McCallum, K., and Waller, L. 2016. Indigenous voices and mediatized policy-making in the digital age. Information, Communication and Society 19(1):23-39.

https://doi.org/10.1080/1369118X.2015.1093534

European Commission, 2019. Trade in seal products. http://ec.europa.eu/environment/biodiversity/animal_welfare/ seals/seal_hunting.htm

Foote, D.C. 1967. Remarks on Eskimo sealing and the harp seal controversy. Arctic 20(4):267-268. https://doi.org/10.14430/arctic3302

Ford, J.D., and Pearce, T. 2012. Climate change vulnerability and adaptation research focusing on the Inuit subsistence sector in Canada: Directions for future research. The Canadian Geographer/Le Géographe Canadien 56(2):275-287. https://doi.org/10.1111/j.1541-0064.2012.00418.x

Ford, J.D., Smit, B., Wandel, J., Allurut, M., Shappa, K., Ittusarjuat, H., and Qrunnut, K. 2008. Climate change in the Arctic: Current and future vulnerability in two Inuit communities in Canada. Geographical Journal 174(1):45-62. https://doi.org/10.1111/j.1475-4959.2007.00249.x

Gioia, D.A., and Chittipeddi, K. 1991. Sensemaking and sensegiving in strategic change initiation. Strategic Management Journal 12(6):433-448. https://doi.org/10.1002/smj.4250120604

GC (Government of Canada). 2016. Government of Canada marks "Seal Day on the Hill 2016." Ottawa: Indigenous and Northern Affairs Canada.

https://www.canada.ca/en/indigenous-northern-affairs/ news/2016/05/government-of-canada-marks-seal-day-on-thehill-2016-.html
. 2017. National Seal Products Day Act. Ottawa: Minister of Justice.

https://laws-lois.justice.gc.ca/eng/acts/N-16.5/page-1.html

GN (Government of Nunavut). 2012. Report on the impacts of the European Union Seal Ban, (EC) NO 1007/2009, in Nunavut. Iqaluit: Department of Environment.

https://www.gov.nu.ca/environment/documents/reportimpacts-european-union-seal-ban-ec-no-10072009nunavut-2012

—_ _ n.d. Sustainable sealing in a traditional economy: Challenges to trade. Iqaluit: Fisheries and Sealing Division, Department of Environment.

https://www.sealingnunavut.ca/Challenges to trade

GNL (Government of Newfoundland and Labrador). 2018. Sealing. St. John's: Fisheries and Land Resources.

https://www.fishaq.gov.nl.ca/sealing/index.html

GNWT (Government of Northwest Territories). 2017. European Union opens door to Inuvialuit seal. Yellowknife: GNWT.

https:/www.gov.nt.ca/en/newsroom/news/european-unionopens-door-inuvialuit-seal

Harter, J.-H. 2004. Environmental justice for whom? Class, new social movements, and the environment: A case study of Greenpeace Canada, 1971-2000. Labour/Le Travail 54:83-119.

Hawkins, R., and Silver, J.J. 2017. From selfie to \#sealfie: Nature 2.0 and the digital cultural politics of an internationally contested resource. Geoforum 79:114-123.

https://doi.org/10.1016/j.geoforum.2016.06.019

He, J. 2015. China-Canada seal import deal after the WTO EUSeal Products Case: At the crossroads. Asian Journal of WTO and International Health Law and Policy 10:223-261.

Herzog, H.A., and Galvin, S.L. 1992. Animals, archetypes, and popular culture: Tales from the tabloid press. Anthrozoös 5(2):77-92.

https://doi.org/10.2752/089279392787011494

Hillier, A., Kelly, R.P., and Klinger, T. 2016. Narrative style influences citation frequency in climate change science. PLoS ONE 11(12): e0167983.

https://doi.org/10.1371/journal.pone.0167983

Hossain, K. 2013. The EU ban on the import of seal products and the WTO regulations: Neglected human rights of the Arctic Indigenous peoples? Polar Record 49(2):154-166.

https://doi.org/10.1017/S0032247412000174

Johnson, H. 2017. \#NoDAPL: Social media, empowerment, and civic participation at Standing Rock. Library Trends 66(2):155-175. https://doi.org/10.1353/lib.2017.0033

Kenny, T.-A., and Chan, H.M. 2017. Estimating wildlife harvest based on reported consumption by Inuit in the Canadian Arctic. Arctic 70(1):1-12. https://doi.org/10.14430/arctic4625

Kerr, J. 2014. Greenpeace apology to Inuit for impacts of seal campaign. Toronto, Ontario: Greenpeace Canada.

https://www.greenpeace.org/canada/en/story/5473/ greenpeace-apology-to-inuit-for-impacts-of-seal-campaign/ 
Knezevic, I., Pasho, J., and Dobson, K. 2018. Seal hunts in Canada and on Twitter: Exploring the tensions between Indigenous rights and animal rights with \#Sealfie. Canadian Journal of Communication 43(3):421-439. https://doi.org/10.22230/cjc.2017v43n3a3376

Lafrance, D. 2017. Canada's seal harvest. Publication No. 2017-18E. Ottawa, Ontario: Library of Parliament.

Laidler, G.J., Ford, J.D., Gough, W.A., Ikummaq, T., Gagnon, A.S., Kowal, S., Qrunnut, K., and Irngaut, C. 2009. Travelling and hunting in a changing Arctic: Assessing Inuit vulnerability to sea ice change in Igloolik, Nunavut. Climatic Change 94(3-4):363-397. https://doi.org/10.1007/s10584-008-9512-z

Leavy, P. 2015. Method meets art: Arts-based research practice, 2nd ed. New York: The Guilford Press.

Miller, A.M.M., and Bush, S.R. 2015. Authority without credibility? Competition and conflict between ecolabels in tuna fisheries. Journal of Cleaner Production 107:137-145. https://doi.org/10.1016/j.jclepro.2014.02.047

Moors, M.R. 2019. What is Flint? Place, storytelling, and social media narrative reclamation during the Flint water crisis. Information, Communication and Society 22(6):808-822. https://doi.org/10.1080/1369118X.2019.1577477

Murphy, D.D. 2006. The tuna-dolphin wars. Journal of World Trade 40(4):597-617.

Newman, J. 2014. Tanya Tagaq beats Arcade Fire, Drake to take Polaris Prize. Rolling Stone, September 23.

https://www.rollingstone.com/music/music-news/throatsinger-tanya-tagaq-beats-arcade-fire-drake-to-take-polarisprize-180246/

O’Connor, K., Drum, D., and Metuq, P. 2017. Wear Qisi-Become seal. Performance Research 22(2):20-26. https://doi.org/10.1080/13528165.2017.1315935

Pelly, D.F. 2001. Sacred hunt: A portrait of the relationship between seals and Inuit. Vancouver, British Columbia: Greystone Books.

Peter, A., Ishulutak, M., Shaimaiyuk, Ju., Shaimaiyuk, Je., Kisa, N., Kootoo, B., and Enuaraq, S. 2002. The seal: An integral part of our culture. Études/Inuit/Studies 26(1):167-174.
Rodgers, K., and Scobie, W. 2015. Sealfies, seals and celebs: Expressions of Inuit resilience in the Twitter era. Interface: A Journal for and about Social Movements 7(1):70-97.

Sanger, C.W. 2010. Review of Icy battleground: Canada, the International Fund for Animal Welfare, and the seal hunt, by Donald Barry. International Journal 61(2):516-518. https://doi.org/10.2307/40204180

Searles, E.Q. 2019. 'Fresh seal blood looks like beauty and life:' \#Sealfies and subsistence in Nunavut. Hunter Gatherer Research 3(4):676-696. https://doi.org/10.3828/hgr.2017.34

Sellheim, N. 2014. The right not to be Indigenous: Seal utilization in Newfoundland. In: Heininen, L., Exner-Pirot, H., and Plouffe, J., eds. Arctic Yearbook 2014. Akureyri, Iceland: Northern Research Forum. 546-552.

Sumner, L.W. 1983. The Canadian harp seal hunt: A moral assessment. International Journal for the Study of Animal Problems 4(2):108-116.

Thornton, A. 1978. The Canadian seal hunt: A reply. New Scientist $78: 82-83$.

Watson, P. 2016. I do not apologize for opposing the slaughter of seals. Pamela Anderson Foundation.

https://www.pamelaandersonfoundation.org/news/2016/1/27/ido-not-apologize-for-opposing-the-slaughter-of-seals-bycaptain-paul-watson

Wenzel, G. 1987. "I was once independent": The southern seal protest and Inuit. Anthropologica 29(2):195-210. https://doi.org/10.2307/25605231

- 1991. Animal rights, human rights: Ecology, economy, and ideology in the Canadian Arctic. Toronto, Ontario: University of Toronto Press.

Wenzel, G.W., Dolan, J., and Brown, C. 2016. Wild resources, harvest data and food security in Nunavut's Qikiqtaaluk region: A diachronic analysis. Arctic 69(2):147-159. https://doi.org/10.14430/arctic4562

Wright, B.G. 2000. Environmental NGOs and the dolphin-tuna case. Environmental Politics 9(4):82-103. https://doi.org/10.1080/09644010008414552

Yang, G. 2016. Narrative agency in hashtag activism: The case of \#BlackLivesMatter. Media and Communication 4(4):13 - 17. https://doi.org/10.17645/mac.v4i4.692 